\title{
Effect of Rooibos and Honeybush Tea Extracts Against Botrytis cinerea
}

\author{
G. Coetzee, I.J. Marx, M. Pengilly, V.S. Bushula, E. Joubert\# and M. Bloom*
}

Department of Microbiology, University of Stellenbosch, Private Bag X1, Matieland 7602, South Africa

\#Post-Harvest \& Wine Technology Division, ARC Infruitec-Nietvoorbij, Private Bag X5026, Stellenbosch 7599, South Africa

Submitted for publication: September 2007

Accepted for publication: February 2008

Key words: Botrytis cinerea, rooibos, Aspalathus linearis, honeybush, Cyclopia spp., tea extracts

\begin{abstract}
Green tea extracts from the indigenous South African rooibos (Aspalathus linearis) and honeybush (Cyclopia species) plants were evaluated as potential antifungal agents against the plant pathogen Botrytis cinerea. When applied at 10 $\mathrm{mg} / \mathrm{ml}$, the tea extracts stimulated biomass production in $B$. cinerea by more than 3 -fold after 24 hrs. This induction could not be linked directly to the presence of selected micro- and macronutrients or antioxidants in the extracts, suggesting a complex set of yet unidentified factors that may act synergistically to enhance cell growth. However, when applied at $100 \mathrm{mg} / \mathrm{ml}$, the $A$. linearis and $C$. genistoides extracts reduced spore germination of $B$. cinerea by $33.3 \%$ and $16.7 \%$, respectively. This suggests that the tea extracts contain active compounds that should be further investigated for their potential as natural anti-fungal agents.
\end{abstract}

Botrytis cinerea is the principle microorganism responsible for 'grey mould' on grapes and other fruits and vegetables that could result in severe crop damage (Ribéreau-Gayon et al., 2006). The fungus is characterised by abundant hyaline conidia (asexual spores) or highly resistant sclerotia that enables it to survive winter or other unfavourable periods (Mendgen \& Hahn, 2002). Grey mould is commonly associated with humid conditions and temperatures of $10-25^{\circ} \mathrm{C}$, with the presence of water on the surface of the grape berry and a temperature of $18^{\circ} \mathrm{C}$ being ideal for germination and mycelial growth (Ribéreau-Gayon et al., 2006). The fungus is a necrotrophic pathogen that actively kills plant cells and subsequently lives on dead tissue. Infection seldom occurs before véraison and is dependent on some kind of damage to the berry skin to provide a point of entry, e.g. physical damage by hail or parasites, or dislodged berries that are imprisoned inside the grape cluster. In addition to the production of antifungal inhibitors, the thick cuticle of the grape berry provides mechanical resistance against $B$. cinerea infection (Ribéreau-Gayon et al., 2006). After véraison, the grape's resistance to $B$. cinerea are weakened due to various chemical and physical changes, with the presence of microperforations of the cuticle and stomatic fissures providing a point of entry for growing hyphae.

Infection by $B$. cinerea in grapes are usually controlled by canopy management, preharvest spraying with fungicides and postharvest sulphur dioxide fumigation (Romanazzi et al., 2007). However, sulphur dioxide causes bleaching of the berries and its residues can be allergenic, while fungicides have little effect if the prevailing weather conditions are inducive to infection (Reino et al., 2004). In the pursuit to develop alternative and safe antimicrobial preservatives, the antimicrobial properties of various plant and herb extracts and essential oils have been investigated (Feng \& Zheng, 2007; Lee et al., 2007; Tzortzakis \& Economakis, 2007; Xu et al., 2007). These natural compounds satisfy consumer demand, since the use of certain hormones and synthetic chemicals have been restricted due to their possible carcinogeni- city and toxicity, long degradation period, environmental pollution and human side effects (Feng \& Zheng, 2007).

Extracts of A. linearis and Cyclopia spp. are known for their anti-oxidant, anti-mutagenic and anti-carcinogenic activities (Von Gadow et al., 1997; Hubbe \& Joubert, 2000; Joubert et al., 2003b; Marnewick et al., 2000, 2005; Van der Merwe et al., 2006). Studies on the phenolic content of C. intermedia E. Mey and C. subternata have revealed the presence of phenolic metabolites thought to have significant pharmacological properties (De Nysschen et al., 1996; Kamara et al., 2003; 2004). The major phenolic compounds in honeybush plant material are the xanthone, mangiferin (a C-glycoside), and the flavanone O-glycoside, hesperidin (Joubert et al., 2003a; Van der Merwe et al., 2006).

In our search for alternative eco-friendly control systems for $B$. cinerea, consideration was given to the possible inhibition of B. cinerea with extracts prepared from rooibos (Aspalathus linearis) and honeybush (Cyclopia species), two indigenous South African plants rich in antioxidants that are used for the production of herbal teas as well as extracts for neutraceutical, health and beauty products. The inhibition of rooibos extracts against $E$. coli and other selected bacterial and yeast strains was previously reported by Schepers (2001). To our knowledge, the efficacy of extracts from $A$. linearis and Cyclopia spp. as anti-fungal agents against $B$. cinerea has not been reported.

\section{MATERIALS AND METHODS}

\section{Plant material and reagents}

Green (unfermented) tea was used as plant material due to the general higher antioxidant content of green tea relative to that of fermented tea (Joubert et al., 2003b). Dried extracts prepared from rooibos (A. linearis) and honeybush (Cyclopia subternata) tea were supplied by Raps GmbH \& Co. (Germany), while the Cyclopia genistoides tea extract was supplied by the Post-Harvest \& Wine Technology Division of ARC Infruitec-Nietvoorbij (Stellenbosch, South Africa). The total antioxidant activity (TAA) of 
the extracts was determined using the $\mathrm{ABTS}^{\bullet+}$ scavenging assay (Re et al., 1999).

Stock solutions of green tea extracts were freshly prepared by dissolving the extract powder in $70 \%$ ethanol at a concentration of $1 \mathrm{~g} / \mathrm{mL}$ with further dilutions as required. All chemicals were of standard or analytical grade and obtained from BDH Chemicals Ltd (Poole, England); Fluka AG (Buchs, Switzerland); Merck (Darmstadt, Germany) or Sigma Chemical Co. (St. Louis, USA).

\section{Strains and culture conditions}

Escherichia coli $\mathrm{DH} 5 \alpha$ was cultured overnight at $37^{\circ} \mathrm{C}$ in Luria Bertani (LB) medium (Hunt et al., 2005) and B. cinerea strain STEU 6253 (Dept. Plant Pathology, Stellenbosch University) in Potato Dextrose (PD) medium at $25^{\circ} \mathrm{C}$ for 7 days (Rauha et al., 2000). All cultures were cultivated under constant agitation (100 $\mathrm{rpm}$ ). Fungal spores were harvested in $100 \mathrm{~mL} 0.85 \%$ sodium chloride containing 1\% Triton X-100 (BDH Chemicals Ltd).

\section{Effect of tea extracts on cell growth in liquid cultures}

Overnight pre-cultures were used to inoculate triplicate sets of $50 \mathrm{~mL}$ LB medium (E. coli) or PD medium (B. cinerea) at a final concentration of $10^{5}$ to $10^{6}$ cells or spores $/ \mathrm{mL}$. Extracts from A. linearis and Cyclopia spp were added at 10 or $100 \mathrm{mg} / \mathrm{mL}$, with the controls not receiving any extract. Bacterial and fungal cultures were kept at $37^{\circ} \mathrm{C}$ and $25^{\circ} \mathrm{C}$, respectively, protected from light to minimise oxidation of the tea extracts. For E. coli, duplicate samples were taken at $0 \mathrm{~h}, 6 \mathrm{~h}, 12 \mathrm{~h}, 24 \mathrm{~h}$ and $48 \mathrm{~h}$ and used to quantify viable bacterial cells by means of duplicate dilution plate counts. Percentage inhibition was expressed as $I=\left[\left(\mathrm{N}_{\mathrm{c}}-\mathrm{N}_{\mathrm{t}}\right) / \mathrm{N}_{\mathrm{c}}\right]$ $\mathrm{x} 100$, where $\mathrm{N}_{\mathrm{c}}$ and $\mathrm{N}_{t}$ represent the viable cell numbers for the control and treatments, respectively.
To determine biomass production by the fungal strains, triplicate samples were taken at $0 \mathrm{~h}, 6 \mathrm{~h}, 12 \mathrm{~h}, 24 \mathrm{~h}, 48 \mathrm{~h}$ and $72 \mathrm{~h}$ of which $1 \mathrm{~mL}$ was centrifuged at $13 \mathrm{~K}$ for 15 minutes. The supernatant was decanted and the pellet dried overnight at $70^{\circ} \mathrm{C}$. Biomass was measured and expressed as mg dry weight $/ \mathrm{mL}$.

Effect of added nutrients and ascorbic acid on biomass production

PD medium with/without $10 \mathrm{mg} / \mathrm{mL}$ extracts from $A$. linearis and C. subternata were analysed for their micro- and macronutrient content (BemLab, Somerset West, South Africa). Based on the respective cation concentrations in $10 \mathrm{mg} / \mathrm{mL}$ A. linearis tea extract, an enriched PD medium was prepared with $48.558 \mathrm{mg} / \mathrm{L}$ $\mathrm{KCl}, 1.929 \mathrm{mg} / \mathrm{L} \mathrm{CaCl}_{2}, 14.885 \mathrm{mg} / \mathrm{L} \mathrm{MgSO}_{4} .7 \mathrm{H}_{2} \mathrm{O}$ and 0.139 $\mathrm{mg} / \mathrm{L} \mathrm{MnCl}_{2} \cdot 4 \mathrm{H}_{2} \mathrm{O}$. Spores from $B$. cinerea were inoculated in triplicate at a final concentration of $10^{5}$ to $10^{6}$ spores $/ \mathrm{mL}$ into PD medium with or without added nutrients, as well as in PD medium plus 10 or $100 \mathrm{mg} / \mathrm{mL}$ ascorbic acid (Sigma Chemical Co., St. Louis, USA) to simulate the antioxidant content of the rooibos extract (TAA of $3204 \mathrm{mmole} / \mathrm{g}$ ). The cultures were incubated at $25^{\circ} \mathrm{C}$ and triplicate samples were taken at $0 \mathrm{~h}, 6 \mathrm{~h}, 12 \mathrm{~h}, 24 \mathrm{~h}, 48 \mathrm{~h}$ and $72 \mathrm{~h}$, of which $1 \mathrm{~mL}$ was centrifuged at $13 \mathrm{~K}$ for 15 minutes and dried overnight at $70^{\circ} \mathrm{C}$. The supernatant was decanted and the pellet dried overnight at $70^{\circ} \mathrm{C}$. Biomass was measured and expressed as $\mathrm{mg} / \mathrm{mL}$ (dry weight).

\section{Spore mortality}

The toxicity of A. linearis and C. genistoides tea extracts to B. $c i$ nerea spores was evaluated as previously described by Karabulut et al. (2005), with minor modifications. In short, $10^{4}$ spores $/ \mathrm{ml}$ B. cinerea spores were mixed with the respective tea extracts (final

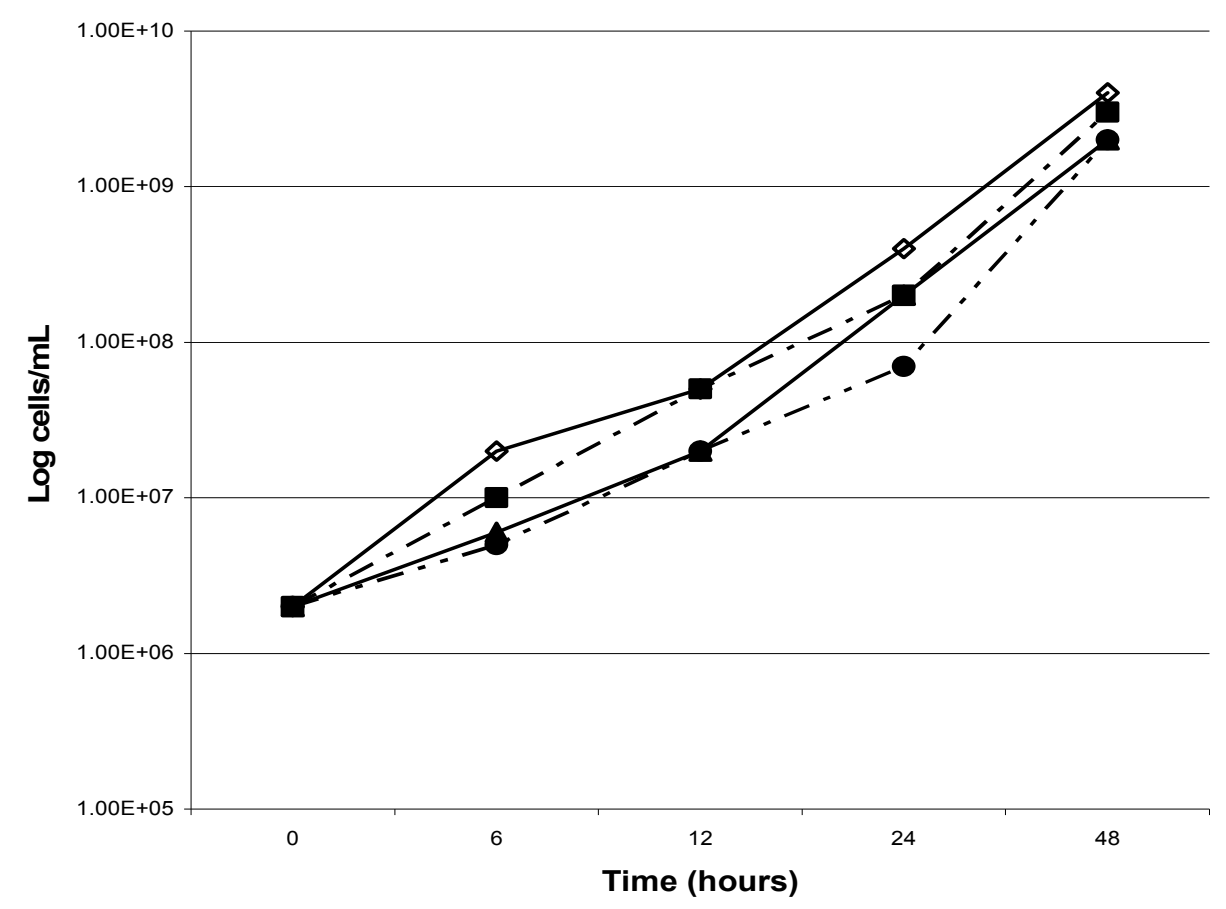

FIGURE 1

The effect of $(\square) 10 \mathrm{mg} / \mathrm{mL}$ A. linearis, $(\boldsymbol{\Delta})$ C. subternata and (-) C. genistoides extracts on viable E. coli cell numbers, when compared to PD medium only $(\diamond)$. 
concentration of $100 \mathrm{mg} / \mathrm{mL})$ at ambient temperature $\left(22-24^{\circ} \mathrm{C}\right)$ in a final volume of $2 \mathrm{~mL}$. After $1 \mathrm{~min}$, triplicate samples of the spore suspensions were diluted 100 -fold in $0.85 \% \mathrm{NaCl}$ of which $100 \mu \mathrm{L}$ were plated onto PD-agar plates. Spores that were exposed to $0.85 \% \mathrm{NaCl}$ without tea extracts were used as a control in each set of experiments. The plates were incubated at $23^{\circ} \mathrm{C}$ for 3 days and the colonies enumerated. Data were expressed as the percentage of germinated spores relative to the control experiment.

\section{RESULTS AND DISCUSSION}

\section{Effect on bacterial and fungal cell growth}

The efficacy of the tea extracts used in the experiments was validated using $E$. coli as a benchmark. In liquid cultures, $10 \mathrm{mg} / \mathrm{mL}$ of the A. linearis, $C$. genistoides and $C$. subternata extracts inhibited growth of $E$. coli cells by $60 \%, 80$ and $85 \%$ respectively after $6 \mathrm{hrs}$, when expressed relative to the control (Fig. 1). After $24 \mathrm{hrs,}$ 25\% and 50\% inhibition by A. linearis and both Cyclopia spp. was observed, but the effect diminished thereafter. This is in line with Schepers (2001) who reported a 35\% cell growth inhibition in $E$. coli after $12 \mathrm{hrs}$ in the presence of a $5.0 \mathrm{~g} / \mathrm{L}$ green rooibos tea extract.

A different phenomenon was observed for the B. cinerea strain: both the $A$. linearis and $C$. subternata extracts induced biomass production by $B$. cinerea more than 5 -fold after $48 \mathrm{hrs}$ when applied at $10 \mathrm{mg} / \mathrm{mL}$ (Fig. 2).

The apparent induction of biomass production by the $B$. cinerea strain in the presence of the tea extracts could be due to the presence of either growth factors (micro- and/or macronutrients) or antioxidants in the tea extract itself that could scavenge free radicals that could otherwise impair cell growth and viability. The antioxidant content of the different extracts as reflected by the
TAA values (mmole Trolox equivalents/g powder), was found to be $3204 \mathrm{mmole} / \mathrm{g}$ for $A$. linearis, $1633 \mathrm{mmole} / \mathrm{g}$ for C. subternata and $1676 \mathrm{mmole} / \mathrm{g}$ for $C$. genistoides.

Effect of added nutrients and antioxidants on biomass production by $B$. cinerea

Chemical analysis of micro- and macronutrients in the growth media supplemented with tea extracts (Table 1) indicated that both the $A$. linearis and $C$. subternata extracts contributed significant levels of especially Potassium (K), Calcium (Ca), Magnesium $(\mathrm{Mg})$ and Manganese $(\mathrm{Mn})$ when added at $10 \mathrm{mg} / \mathrm{mL}$ to PD medium.

The PD medium containing $10 \mathrm{mg} / \mathrm{mL}$ A. linearis tea extract induced biomass production of $B$. cinerea by $2-3$-fold at $48 \mathrm{hrs}$ (Figure 3). Similar trends were observed with the $C$. subternata extract (data not shown). However, no significant induction in biomass production of $B$. cinerea was observed when cultured in an enriched Potato Dextrose (PD) medium containing $\mathrm{K}, \mathrm{Ca}$, $\mathrm{Mg}$ and $\mathrm{Mn}$ ions at similar concentrations identified in $10 \mathrm{mg} / \mathrm{ml}$ extract of $A$. linearis. It is thus clear that the induced biomass production in the presence of the tea extracts could not be ascribed to the mere presence of these nutrients in the tea extracts.

When applied at $100 \mathrm{mg} / \mathrm{mL}$, the A. lineraris and C. subternata extracts induced biomass production by more than 4-fold and 6-fold after $48 \mathrm{hrs}$ and $72 \mathrm{hrs}$, relative to the control, with indications of a continued induction thereafter. However, only a 3-fold induction in biomass production of $B$. cinerea was observed in the presence of $100 \mathrm{mg} / \mathrm{mL}$ ascorbic acid at $48 \mathrm{hrs}$, with a steep decline thereafter. Given the TAA activity of $3783 \mathrm{mmole} / \mathrm{g}$ for ascorbic acid, 3204 mmole/g for A. linearis and $1633 \mathrm{mmole} / \mathrm{g}$ for C. subternata, it is clear that the antioxidant activity of the tea extract per se was not re-

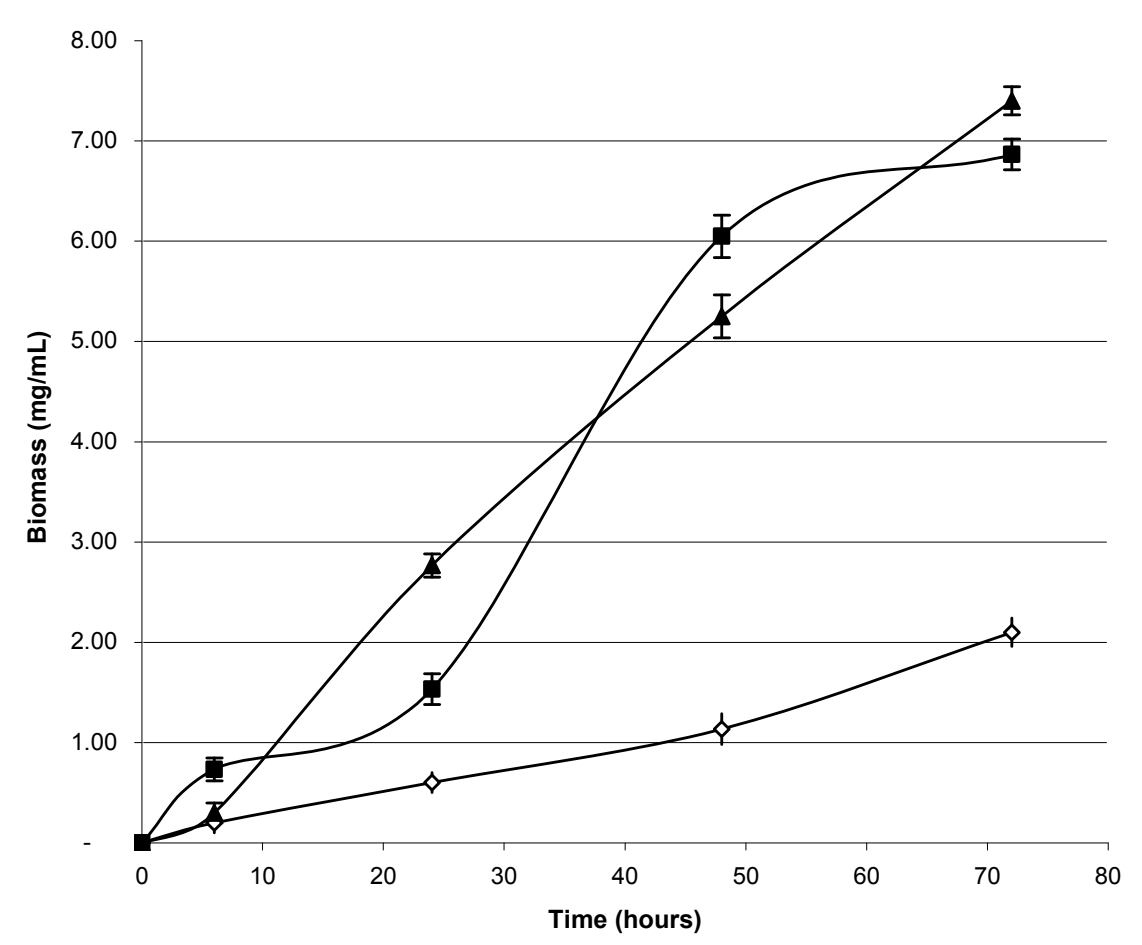

FIGURE 2 


\section{TABLE 1}

Quantification of micronutrients (expressed as $\mathrm{mg} / \mathrm{L}$ ) contributed by Potato Dextrose medium and $10 \mathrm{mg} / \mathrm{mL}$ tea extracts. Cation concentrations in bold indicate those that were more than $50 \%$ higher in the extracts than in the control PD medium.

\begin{tabular}{|c|c|c|c|c|c|c|c|c|c|c|c|}
\hline Media & $\mathbf{N}$ & $\mathbf{P}$ & $\mathbf{K}$ & Ca & Mg & $\mathbf{N a}$ & Mn & $\mathbf{F e}$ & $\mathbf{C u}$ & $\mathbf{Z n}$ & B \\
\hline Potato Dextrose Medium (PD) & 0.323 & 3.815 & 100.894 & 3.071 & 0.585 & 121.050 & 0.077 & 3.230 & 0.001 & 0.172 & 0.420 \\
\hline $\begin{array}{l}\mathrm{PD} \text { medium }+10 \mathrm{mg} / \mathrm{mL} \\
\text { C. subternata extract }\end{array}$ & 0.429 & 4.397 & 169.143 & 3.607 & 6.681 & 136.541 & 0.121 & 3.548 & 0.025 & 0.187 & 0.455 \\
\hline $\begin{array}{l}\mathrm{PD} \text { medium }+10 \mathrm{mg} / \mathrm{mL} \\
\text { A. linearis extract }\end{array}$ & 0.366 & 4.116 & 149.452 & 5.000 & 15.470 & 175.630 & 0.216 & 3.359 & 0.004 & 0.219 & 0.633 \\
\hline
\end{tabular}

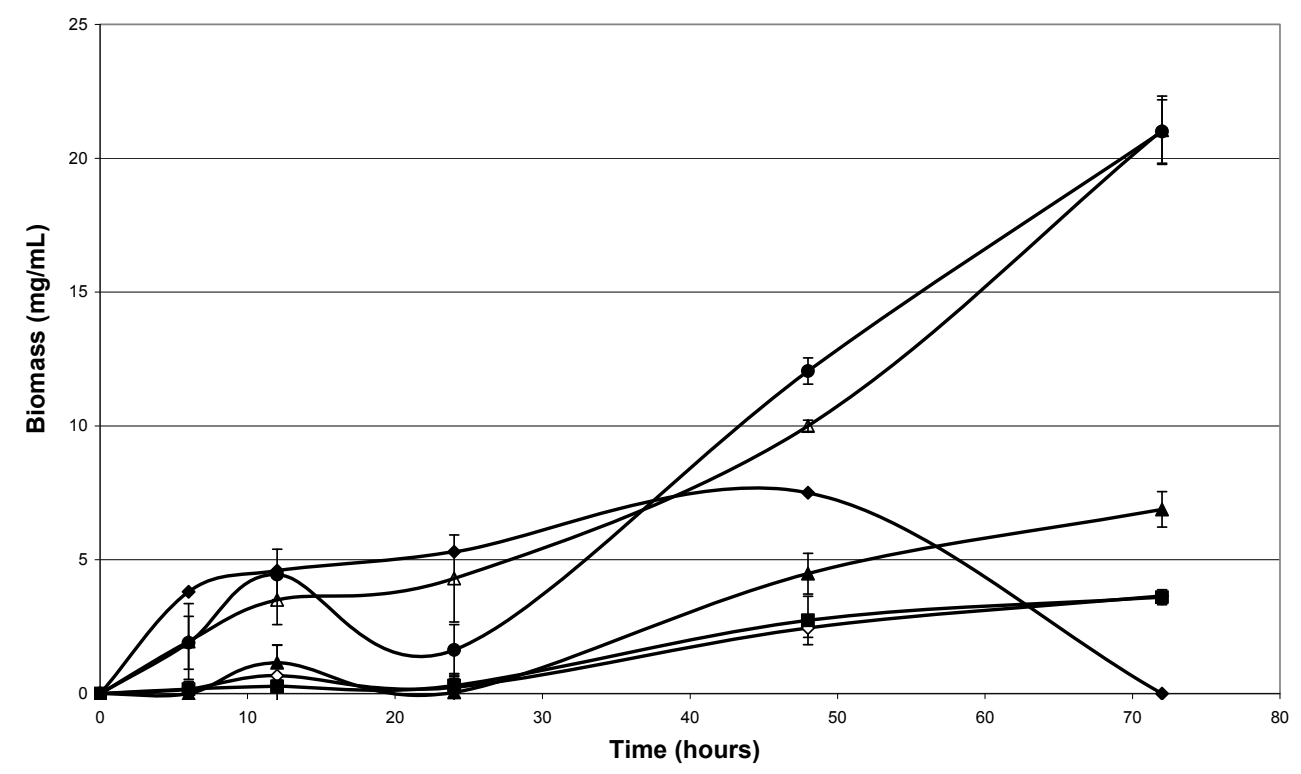

FIGURE 3

The effect of $(\square)$ added nutrients representing the major cations in $10 \mathrm{mg} / \mathrm{mL}$ A. linearis, as apposed to $(\boldsymbol{\Delta}) 10 \mathrm{mg} / \mathrm{mL}$ or $(\triangle) 100 \mathrm{mg} / \mathrm{mL}$ A. linearis extract, (๑) $100 \mathrm{mg} / \mathrm{mL}$ C. subternata extract, and $(\diamond) 100 \mathrm{mg} / \mathrm{mL}$ ascorbic acid on biomass formation by $B$. cinerea (dry weight), when compared to PD medium only $(\diamond)$.

sponsible for the induced biomass production observed in the presence of the tea extracts. On the contrary, the PD medium containing ascorbic acid showed an initial increase in biomass similar to that of the tea extracts, followed by a steep decline in biomass towards $72 \mathrm{hrs}$, which suggest cell death as apposed to the further increase in biomass observed for the tea extracts.

\section{Inhibition of spore germination in $\boldsymbol{B}$. cinerea}

Exposure of $B$. cinerea spores to A. linearis or C. genistoides tea extracts reduced spore germination by $36 \%( \pm 0.7 \%)$ and $19 \%$ $( \pm 0.8 \%)$, respectively (Figure 4$)$. The antioxidant content of the A. linearis extract (3204 nmole/g) was almost double that of the C. genistoides extract (1676 nmole/g), which may account for the different levels of inhibition of spore germination observed for the two tea extracts.

The antimicrobial effect of Chinese green tea has been directly linked to the presence of two bioactive flavanols namely, epicatechin gallate and epigallocatechin gallate (Si et al., 2006). This suggests that the antifungal property of the tested tea extracts may be due to the presence of a specific flavanol or a combination of different flavanoids. Both rooibos and honeybush tea extracts are known to contain different phenolic compounds, including epicatechin gallate and epigallocatechin gallate (Kamara et al., 2003; Kamara et al., 2004; Rabe et al., 1994).

The inhibition of $B$. cinerea spore germination observed for the A. linearis or $C$. genistoides tea extracts suggests the potential use of these extracts as antifungal agents. The use of chemicals such as sulfur dioxide and the emergence of fungicide-resistant strains within vineyard populations are all important factors driving the development of alternative antifungal agents. Currently, different essential oils, plant extracts and other substances are evaluated for their antifungal properties with regard to $B$. cinerea. These include grapefruit seed extract, chitosan, essential oils of thyme, sage and nutmeg, ethanol, potassium sorbate and carvacrol (Martínez-Romero et al., 2007; Karabulut et al., 2005; Feng and Zheng, 


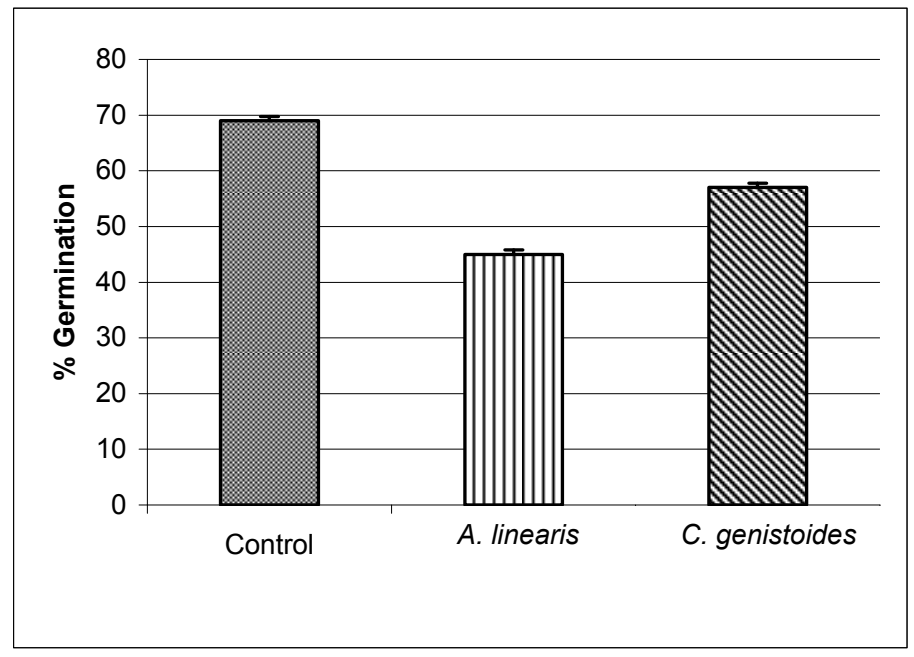

FIGURE 4

Germination of $B$. cinerea spores on PDA plates after exposure to $0.85 \% \mathrm{NaCl}$ without tea extract (control), $100 \mathrm{mg} / \mathrm{ml}$ A. linearis extract and $100 \mathrm{mg} / \mathrm{ml} \mathrm{C}$. genistoides extract for $1 \mathrm{~min}$.

2007; Xu et al., 2007). It will be of great interest to isolate and identify these compounds and test their efficacy against a range of bacterial and fungal pathogens.

\section{CONCLUSIONS}

Results from this study showed that extracts from $A$. linearis and Cyclopia spp. have potential for inhibiting bacterial growth by $60 \%-85 \%$ when applied at $10 \mathrm{mg} / \mathrm{mL}$. Both the rooibos and honeybush tea extracts have a bacteriostatic effect on $E$. coli cells, with the inhibitory effect diminishing after $48 \mathrm{hrs}$. If the anti-microbial efficacy of the tea extracts is linked to polyphenolic compounds in the extracts, it is likely that the anti-microbial efficacy of the respective tea extracts may diminish over time due to instability or oxidation of the active compound(s). Future studies can be done to isolate, identify and stabilise the anti-microbial components in the tea extracts with the intention to improve their efficacy.

In contrast to the observations with $E$. coli, the $B$. cinerae strain showed a significant increase in biomass production when cultured in the presence of extracts from A. linearis or Cyclopia spp. This may be ascribed to the presence of micro- and macronutrients, such as metal ions, in the tea extracts that are stimulating cellular growth. However, when some of the dominant micro- and macronutrients identified in the $A$. linearis extract were included in the growth medium, the effect was 2-fold less than in the presence of the tea extracts. The results also suggest that the mere presence of an antioxidant could not induce biomass production by $B$. cinerea. In fact, the $C$. subternata extract (TAA of 1633 mmole/g) was as effective as the A. linearis extract (TAA of 3204 $\mathrm{mmole} / \mathrm{g}$ ), with ascorbic acid (TAA of $3783 \mathrm{mmole} / \mathrm{g}$ ) resulting in a two-fold less induction than the tea extracts after $48 \mathrm{hrs}$.

Tea extracts from A. linearis and $C$. genistoides decreased the spore viability of $B$. cinerea by $36 \%$ and $19 \%$, respectively, suggesting that the extracts contain chemical compounds that could have potential as antifungal agents. However, these active compounds have to be isolated, identified and evaluated individually to ascertain their effect on $B$. cinerea. A better understanding of the active compounds will also assist us in elucidating the appar- ent conflicting effects on $B$. cinerea, i.e. the inhibition of spore germination and induction of biomass production observed in the presence of both $A$. linearis and $C$. genistoides extracts.

\section{PATENT PENDING}

Results presented here have been included in a patent entitled, "Plant extract having antimicrobial activity", filed with the South African patent office (ZA2007/08879).

\section{LITERATURE CITED}

De Nysschen, A.M., Van Wyk, B.E., Van Heerden, F.R. \& Schutte, A.L., 1996. The major phenolic compounds in the leaves of Cyclopia species (Honeybush tea). Biochem. Syst. Ecol. 24, 243-246.

Feng, W. \& Zheng, X. 2007. Essential oils to control Alternaria alternate in vitro and in vivo. Food Control. 18, 1126-1130.

Hubbe, M.E. \& Joubert, E., 2000. In vitro superoxide anion radical scavenging ability of honeybush tea (Cyclopia). In: Johnson, I.T. \& Fenwick, G.R. (eds). Dietary anticarcinogens and antimutagens. Chemical and biological aspects. Royal Chemistry Society, UK, pp. 242-244.

Hunt, C., Gillani, N., Farone, A., Rezaei, M. \& Kline P.C., 2005. Kinetic isotope effects of nucleoside hydrolase from Escherichia coli. Bioch. Biophys. Acta.. $1751,140-149$

Joubert, E., Otto, F, Grüner, S. \& Weinreich, B., 2003a. Reversed-phase HPLC determination of mangiferin, isomangiferin and hesperidin in Cyclopia and the effect of harvesting date on the phenolic composition of $C$. genistoides. Eur. Food Res. Technol. 216, 270-273.

Joubert, E., Winterton, P. Britz, T.J. \& Ferreira, D., 2003b. Superoxide anion radical and a,a-diphenyl-b-picrylhydrazyl radical scavenging capacity of rooibos (Aspalathus linearis) aqueous extracts, crude phenolic fractions, tannin and flavonoids. Food Res. Int. 37, 133-138.

Kamara, B.I., Brand, J., Brandt, E.V. \& Joubert, E., 2004. Phenolic metabolites from from honeybush tea (Cyclopia subternata). J. Agric. Food Chem. 52, 5391-5395.

Kamara, B.I., Brandt, E.V., Ferreira, D. \& Joubert, E., 2003. Polyphenols from Honeybush Tea (Cyclopia intermedia). J. Agric. Food Chem. 51, 3874-3879.

Karabulut, O.A., Romanazzi, G., Smilanick, J.L. \& Lichter, A., 2005. Postharvest ethanol and potassium sorbate treatments of table grapes to control grey mold. Postharvest Biol. Tech. 37, 129-134.

Lee, S-H., Chang, K-S., Su, M-S., Huang, Y-S. \& Jang, H-D., 2007. Effects of some Chinese medicinal plant extracts on five different fungi. Food Control 18, 1547-1554. 
Marnewick, J.L., Gelderblom, W.C.A. \& Joubert, E., 2000. An investigation on the antimutagenic properties of South African herbal teas. Mutat. Res. 471, 157-166.

Marnewick, J.L., Joubert, E., Joseph, S., Swanevelder, S., Swart, P. \& Gelderblom, W.C.A., 2005. Inhibition of tumour promotion in mouse skin by extracts of rooibos (Aspalathus linearis) and honeybush (Cyclopia intermedia), unique South African. Cancer Lett., 224, 193-202.

Martínez-Romero, D., Guillén, F., Valverde, J.M., Bailén, G., Zapata, P., Serrano, M., Castillo, S. \& Valero, D., 2007. Influence of carvacrol on survival of Botrytis cinerea inoculated in table grapes. Int. J. Food Microbiol. 115, 144-148.

Mendgen, K. \& Hahn, M., 2002. Plant infection and the establishment of fungal biotrophy, Trends Plant Sci. 7, 352-356.

Rabe, C., Steenkamp, J.A., Joubert, E., Burger, J.F.W. \& Ferreira, D., 1994. Phenolic metabolites from rooibos tea (Aspalathus linearis). Phytochem. 35, $1559-1565$.

Rauha, J. -P., Remes, S., Heinonen, M., Hopia, A., Kähkönen, M., Kujala, T., Pihlaja, K., Vuorela, H. \& Vuorela, P., 2000. Anti-microbial effects of Finish plant extracts containing flavonoids and other phenolic compounds. Int. J. Food Microbiol. 56, 3-12.

Re, R., Pellegrini, N., Proteggente, A., Pannala, A., Yang, M. \& Rice-Evans, C., 1999. Antioxidant activity applying an improved ABTS radical cation assay. Free Rad. Biol. Med., 26, 1231-1237.

Reino, J.L., Hernandez-Galan, R., Duran-Patron, R. \& Collado, I.G., 2004. Virulence-toxin production relationship in isolates of the plant pathogenic fungus Botrytis cinerea. J. Phytopathol. 152, 563-566.
Ribereau-Gayon, P., Dubourdieu, D. \& Doneche, B. 2006. The Microbiology of Wine and Vinifications ( $\left.2^{\text {nd }} \mathrm{ed}\right)$. Wiley, Chichester.

Romanazzi, G., Karabulut, O.A. \& Smilanick, J.L., 2007. Combination of chitosan and ethanol to control postharvest gray mold of table grapes. Postharvest Biology and Technology. In Press, Corrected Proof, Available online 27 February 2007.

Schepers, S., 2001. Anti-microbial activity of rooibos tea (Aspalathus linearis) on food spoilage and potential pathogens. Thesis, Stellenbosch University, Private Bag X1, 7602, Matieland (Stellenbosch), South Africa.

Si, W., Gong, J., Tsao, R., Kalab, M., Yang, R., \& Yin, Y., 2006. Bioassay-guided purification and identification of antimicrobial compounds in Chinese green tea extract. J. Chromatogr A. 1125, 204-210.

Tzortzakis, N.G. \& Economakis, C.D., 2007. Antifungal activity of lemongrass (Cympopogan citrates L.) essential oil against key postharvest pathogens. Innov. Food Sci. \& Emerging Technologies. 8, 253-258.

Van der Merwe, J.D., Joubert, E., Richards, E., Manley, M, Snijman, P.W., Marnewick, J.L. \& Gelderblom, W.C.A., 2006. A comparative study on the antimutagenic properties of aqueous extracts of Aspalathus linearis (rooibos), different Cyclopia spp. (honeybush) and Camellia sinensis teas. Mut. Res. 611, 42-53.

Von Gadow, A., Joubert, E. \& Hansmann, C.F., 1997. Comparison of the antioxidant activity of rooibos tea (Aspalathus linearis) with green, oolong and black tea. Food Chem. 60, 73-77.

Xu, W-T., Huang, K-L., Guo, F., Qu, W., Yang, J-J., Liang, Z-H. \& Luo, Y-B. 2007. Postharvest grapefruit seed extract and chitosan treatments of table grapes to control Botrytis cinerea. Postharvest Biol. Tech. 46, 86-94. 